\title{
Microbiological Quality on Food Handles' Hands
}

\author{
Sarah Hellen Mendonça Ferreira (I), Karyne Oliveira Coelho (I), \\ Aracele Pinheiro Pales dos Santos (I), Cláudia Peixoto Bueno (I)
}

(I) UEG - Universidade Estadual de Goiás (Rua da Saudade, n־56 - Vila Eduarda - São Luís de Montes Belos - GO - CEP 76.100)

\section{Resumo}

Food quality can be determined through quality analytical control. Microbial quality can be established using microorganisms, like the coliform group, as indicators of fecal contamination. Usually food borne illness is caused by bacteria and in most cases the contamination are result from an inadequate handling and poor sanitary conditions. Therefore, the objective of this study was to evaluate the hygienic-sanitary quality from the food handlers' hands in a dairy industry in São Luís de Montes Belos micro-region in Goias state. The study evaluated 102 swab samples from food handlers' hands. The most probable number of total coliform, thermotolerant coliforms and counting of aerobic mesophilic microorganism. The "swab test" was utilized in order to determine the relative values of handler condition at work operational area. The standard suggested by reference values in a specialized literature are: 1,0 x 102 CFU/hand for aerobic mesophilic microorganism counts, $10 \mathrm{CFU} / \mathrm{hand}$ of most probable number of total coliforms and zero CFU/hand for thermotolerant coliforms. The results were analyzed by descriptive statistics using absolute and relative frequency in order to compare to standard reference values. There was no total coliform or thermotolerant contamination in the samples analyzed; however, the results showed that $23.52 \%$ (24/102) from the swab samples analyzed were positive for aerobic mesophilic microorganism which is above the limit recommended by standard reference values. Therefore it is essential certify the food handlers training in order to provide a better final dairy product quality. Microbial

\footnotetext{
Referência:

Sarah Hellen Mendonça Ferreira, Karyne Oliveira Coelho, Aracele Pinheiro Pales dos Santos, Cláudia Peixoto Bueno. Microbiological Quality on Food Handles' Hands. In: Anais do 12 Congresso Latinoamericano de Microbiologia e Higiene de Alimentos - MICROAL 2014 [= Blucher Food Science Proceedings, num.1, vol.1]. São Paulo: Editora Blucher, 2014. 
quality aims to produce safe food in terms of microbiological patterns. To achieve this goal of safe food, food handlers must be properly trained. These efforts will prevent food-borne diseases

Palavras-Chave: Asepsis, collaborators, hygiene, quality Agência de Fomento: 